\title{
García Falcón, Marco (2017). Esta casa vacía. Lima: Peisa.
}

Esta casa vacía ${ }^{1}$, tercera novela de Marco García Falcón (Lima, 1970), narra la catarsis literaria a la que se somete Giovanni Perleche, escritor, profesor y corrector de estilo de 42 años, como único mecanismo salvador ante la pérdida de su familia (esposa e hijo) y el sentido de su propia vida. La obra está dividida en dos partes. El relato que el protagonista nos presenta de manera testimonial y reflexiva surge como una suerte de confesión vertiginosa, con ansias de ser escuchado, leído y entendido. El comunicarse con un otro ideal e imaginario lo reconforta; más aún cuando decide, una vez terminada su catarsis, que el destinatario de aquellas páginas será, en un futuro, su hijo.

Perleche inicia su historia de manera estratégica: parte de lo sensible. Narra el nacimiento de su hijo Tadeo y las complicaciones que tuvo su esposa Micaela en el parto. Poco a poco va acercando al lector a aquel retrato familiar (ahora quebrado), en donde él mismo se configura como una presencia fantasmal. Se trata, pues, de una narración contada a través de los recuerdos y la nostalgia de haberlos perdido. El protagonista, a través de un lenguaje simple y fluido, en ocasiones haciendo uso de metáforas que logran embellecer su relato subjetivo, va introduciendo su mundo personal en las letras. Confiesa sus primeros años de vida en pareja con Micaela, la aparición de Tamara (su alumna y amante), el arrepentimiento, la reconquista de su esposa y el nacimiento de su hijo Tadeo.

Esta nueva etapa en la vida de Perleche como padre de un niño con salud precaria afecta su plan de vida soñado. El exceso de trabajo, las deudas, el estrés, las drogas, los estupefacientes, una nueva infidelidad, además de la violencia que ejerce contra su hijo, terminan produciendo el estado en que lo encontramos al iniciar el texto. Micaela y Tadeo lo han abandonado. El protagonista lo ha perdido todo. La escritura parece ser el único mecanismo de supervivencia de Perleche. La escritura y la literatura logran lanzarlo a la superficie. "Mientras uno escribe, nunca está solo", reflexiona el personaje. Aquella parece ser la única forma que le permite evadirse de una realidad que lo atormenta y que, a la vez, le revela las 
causas de su desmoronamiento físico y emocional. La escritura como catarsis le facilita seguir viviendo, refuerza su esperanza y le permite entender mejor su situación: "Y con absoluta lucidez soy consciente de las batallas que he perdido, de las otras que todavía libro tenaz, silenciosamente, y también de que estoy vivo, magullado o atenazado o ensombrecido pero vivo" (p. 17).

Si bien hablamos de la literatura y la escritura como una suerte de refugio mental, es preciso mencionar los refugios "reales" que el protagonista busca a lo largo de su historia. Uno de ellos es, claramente, el departamento que construye con gran esfuerzo en la casa de sus suegros. Aquel espacio, que termina siendo abandonado por su esposa, su hijo y él mismo, se convierte en su meta obsesiva. Perleche parece creer que al construir una casa está construyendo un hogar. Por otro lado, tenemos la presencia del carro, un Volkswagen celeste, descrito como su "pequeña casa movible". Aquel auto está cargado de un mayor grado de afectividad, puesto que le otorga la libertad que no le permite su nueva vivienda. Su casa no le pertenece, la siente ajena, ya que es, al fin y al cabo, una suerte de invasión en el espacio de los suegros.

La búsqueda de refugios alternos lo lleva a encontrar drogas, estupefacientes y sexo, los cuales le producen un alivio momentáneo. Es curioso descubrir en un determinado pasaje que elementos naturales como el mar y el viento también producen en Giovanni Perleche una sensación de protección, calma y amparo:

$\mathrm{Y}$ ya no tengo miedo. $\mathrm{Y}$ ya no hay nada que se interponga a mis movimientos salvo la suave sensación del agua sobre mi cuerpo. Y de las olas. Y del ondular del viento que todo lo arrulla y todo lo cura: dulce morada para tanto cansancio. (p. 116)

Estamos ante un personaje que se siente atormentado por la rutina y el hastío que le produce su existencia; asimismo, su incapacidad de crear vínculos con el otro lo hunde en una soledad que intenta amortiguar sin éxito. Una vez más, solo la escritura va a permitirle ordenar sus pensamientos y recuperar el rumbo perdido. 
Marco García Falcón logra, a través de la introspección de su personaje, asentar una complicidad y cercanía con sus lectores en diversos pasajes del libro. La vida acelerada y vertiginosa del protagonista corresponde, sin duda, al ritmo de vida de una sociedad consumista (con la que nos podemos identificar en la actualidad) que exige siempre más de cada individuo. Las familias sobreviven mediante créditos infinitos, sin poder librarse jamás de sus deudas. Se hace imposible vivir a costa de un solo trabajo. Giovanni Perleche tiene cada vez menos tiempo para compartir con su familia. La falta de comunicación se impone. De esta manera, sus pesares son atenuados no solo por vicios y sexo, sino por creencias que van más allá de todo entendimiento positivista: religión, medicina alternativa y esoterismo. El autor comparte un pesar y un sentimiento colectivos que trascienden la obra ficcional, pero lo atenúa con un futuro esperanzador, como se muestra al final del libro.

En tal sentido, es rescatable su prosa clara, sin ambigüedades que dificulten la lectura. Sin embargo, para un lector más exigente, la trama y la posición del protagonista frente a distintas situaciones puede incurrir en una falta de sorpresa narrativa y una sensación de inverosimilitud literaria, lo cual es un grave delito en el mundo de las letras. Si bien García Falcón tiene aciertos en su novela como lo es la ya aclamada prosa, así como los pasajes reflexivos y los párrafos dedicados al pequeño Tadeo, en donde el lenguaje fluye de forma poética, la cotidianidad de la historia no genera mayor sorpresa. A veces, quizás, es necesario tomar un mayor riesgo a la hora de plasmar una confesión, un desquite narrativo, y no sentarse cómodamente y hablar desde una posición de vulnerabilidad comprensiva, ni creer que la escritura es solo una forma de esperanza.

\section{Notas}

1 Obra ganadora del Premio Nacional de Literatura 2018 en la categoría Novela.

\section{Melanie Pastor Boza}

Universidad Nacional Mayor de San Marcos, Lima, Perú

Contacto: melanie.pastor@unmsm.edu.pe

https://orcid.org/0000-0001-7481-9893 